\title{
Loan Supply Shocks in Macedonia: A Bayesian SVAR Approach with Sign Restrictions
}

\section{Rilind Kabashi}

Monetary Policy and Research Department, National Bank of the Republic of Macedonia, Skopje, Republic of Macedonia kabashir@nbrm.mk

\section{Katerina Suleva}

Monetary Policy and Research Department, National Bank of the Republic of Macedonia, Skopje, Republic of Macedonia sulevak@nbrm.mk
CroEconsur

Vol. 18

No. 1

June 2016

pp. 5-33

Received: March 11, 2016

Accepted: June 10, 2016

Research Article

doi:10.15179/ces.18.1.1

\section{Abstract}

This paper analyzes the effects of loan supply, as well as aggregate demand, aggregate supply and monetary policy shocks between 1998 and 2014 in Macedonia using a structural vector autoregression model with sign restrictions and Bayesian estimation. The main results indicate that loan supply shocks have no significant effect on loan volumes and lending rates, or on economic activity and prices. The effects of monetary policy on lending activity are fairly limited, although there is some evidence that it affects lending rates more than loan volumes. Monetary policy shocks have strong effects on inflation, while the central bank reacts strongly to adverse shocks hitting the economy. Baseline results are confirmed by several robustness checks. According to historical decomposition, the lending activity was supporting economic growth before and during the crisis, but its contribution became negative during the recovery and it was a drag on growth until the end of the period. Pre-crisis GDP growth is mostly explained 
by supportive monetary policy. However, the restrictive monetary policy during the crisis contributed to the fall of GDP, before becoming supportive again during the early stages of the recovery. Policy rates in recent years mostly reflect subdued lending activity and aggregate supply factors, which the central bank tries to counteract with a more accommodative policy.

Keywords: loan supply, monetary policy, Bayesian VAR, sign restrictions, Macedonia

JEL classification: C11, C32, E51, E52

\section{Introduction ${ }^{1}$}

The issue of loan supply shocks has been gaining attention in the literature, mostly as a reflection of the financial crisis and its effects on domestic economic activity. Most empirical studies on loan supply shocks use Bayesian SVAR with sign restrictions. Barnett and Thomas (2014) find that loan supply shocks explain most of the weakness in lending in the UK since the onset of the crisis and between a third and a half of the fall in GDP below its historic trend. Halvorsen and Jacobsen (2014) also find that lending shocks explain between 10 and 20 percent of output gap variance in Norway and the UK. Regarding the euro area, Hristov, Hülsewig and Wollmershäuser (2012) find that loan supply shocks have had a strong effect on lending and GDP growth during the financial crisis, with some cross-country heterogeneity regarding the timing and the magnitude of the shocks. Studies on Hungary (Tamási and Világi, 2011) and on Australia, Canada and the UK (Finlay and Jääskelä, 2014), also find that the role of loan supply shocks in the recent crisis was important, although it was not dominant.

This paper analyzes the effects of loan supply shocks in Macedonia between 1998 and 2014, as well as the effects of other key macroeconomic shocks, i.e.,

1 The views expressed in this paper are those of the authors and do not necessarily represent the views of the National Bank of the Republic of Macedonia. The authors are grateful to Haroon Mumtaz of the Queen Mary University of London for sharing his code and for the helpful advice provided. We are also grateful to four anonymous referees, as well as to the participants of the 19th Session of the NBRM Researchers' Club for useful comments. 
monetary policy, aggregate demand and aggregate supply shocks. It follows the recent literature on loan supply shocks, particularly regarding the empirical methodology. The main contribution of the paper is that it focuses on an important economic and policy issue in Macedonia, which has not been previously empirically investigated. By using Bayesian SVAR with sign restrictions, the paper avoids some of the drawbacks of classical econometric methods arising from the relatively short data series with structural and methodological breaks, which is common for transition countries. To the best of our knowledge, this is the first paper which tries to apply this technique to economic data on Macedonia.

The paper starts with discussing data and methodology in Section 2. Section 3 presents baseline results. Section 4 provides robustness checks. The last section provides a conclusion.

\section{Data and Methodology}

\subsection{Data}

In the early years of the transition period, economic growth in Macedonia was volatile, while lending activity was anaemic. During that period, the country was also hit by several large internal and external shocks. Consequently, the central bank (National Bank of the Republic of Macedonia, NBRM) was mostly implementing a restrictive monetary policy in order to eliminate pressures on foreign reserves and to maintain the fixed exchange rate.

An expansion of bank lending started around the early 2000s, following the reforms of the banking system and wider structural and institutional reforms. Combined with the stable macroeconomic environment and the absence of external shocks, the higher lending was associated with acceleration in economic growth rates (Figure 1). With no significant pressures on the price level and the current account, the central bank was able to maintain the exchange rate peg to the euro, while at the same time relaxing the monetary policy. However, the 
global crisis put an end to this process. Post-crisis economic growth has been lower or slightly negative (in 2009 and 2012), while lending growth rates are continuously lower than in the pre-crisis period and remain at a moderate level. In addition, the central bank had to fight pressures on foreign reserves by raising policy rates and additional restrictive measures during the first wave of the crisis. Nevertheless, as the pressure subsided, the central bank was able to relax its policy in order to support economic activity.

Figure 1: Stylized Facts, Annual Data (quarterly data for policy rates and NBRM interventions)

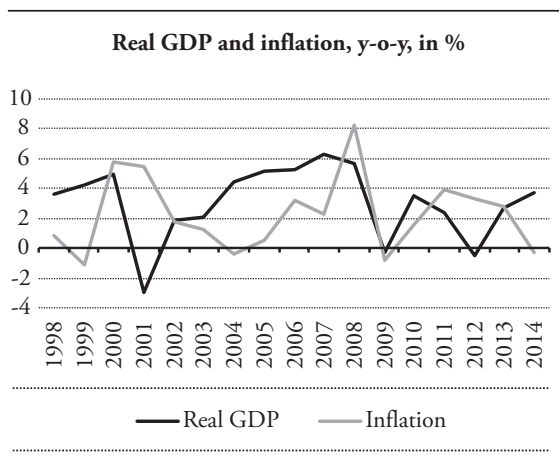
Policy rate and NBRM interventions on the foreign exchange market, in \%

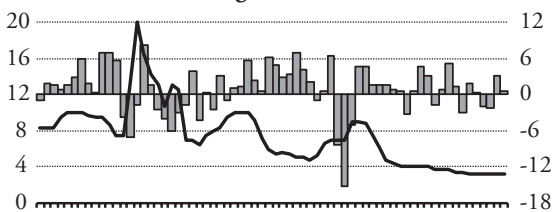

$\vec{\sigma} \vec{\sigma} \vec{\sigma} \vec{\sigma} \vec{\sigma} \vec{\sigma} \vec{\sigma} \vec{\sigma} \vec{\sigma} \vec{\sigma} \vec{\sigma} \vec{\sigma}$

๙

Interventions, in \% of quarterly GDP (right axis)

- Policy rate
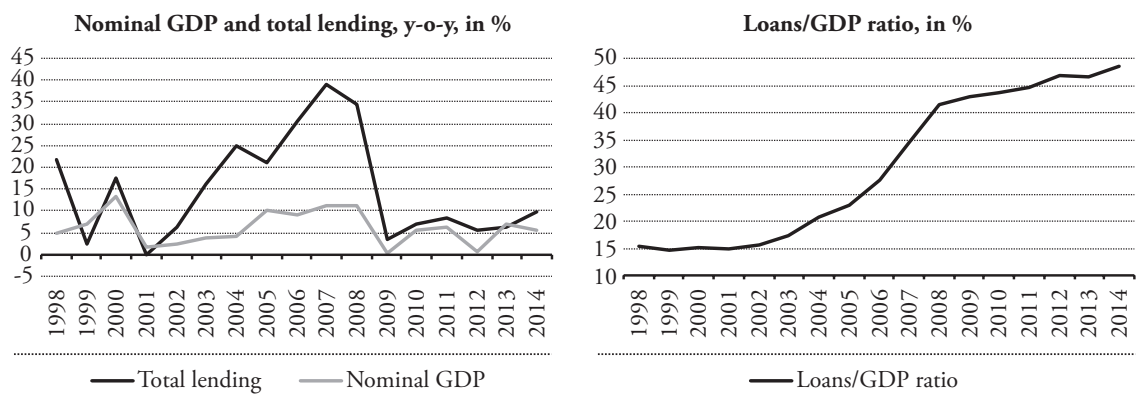

Sources: NBRM and State Statistical Office.

In our analysis, we use quarterly data between 1998Q1 and 2014Q4 (Figure 2), which is the maximum sample available at the time of writing. Standard 
information criteria indicate that a VAR of two lags is appropriate. The variables included in our baseline VAR are: the seasonally-adjusted quarter-on-quarter real GDP growth, the seasonally-adjusted quarter-on-quarter CPI inflation rate, the policy rate (rate on central bank bills), the quarter-on-quarter change in total outstanding volume of local currency (denar) loans and the corresponding average weighted lending rate, i.e., the rate on the total outstanding volume of denar loans. We also include a constant term in the VAR. Although most studies use the GDP deflator as an indicator of price movements, we decided to use consumer price inflation because it is the indicator monetary policy-makers usually focus on when making policy decisions (Halvorsen and Jacobsen, 2014), which is also the case in Macedonia. Further, by using the policy rate, we deviate from most of the literature, which tends to use interbank rates as an indicator of the monetary policy stance. However, in circumstances of continuous surplus liquidity in the banking system, the interbank money market in Macedonia is relatively shallow and its role is fairly limited. In addition, the correlation between policy rates and money market rates is very high, and policy rates are fully transmitted to money market rates (Veličkovski, 2006; Bogoev and Petrevski, 2012). Related to this, while our use of the policy rate as a representative of monetary policy is in line with the relevant literature, this also implies that we abstract from additional instruments and measures that the NBRM has occasionally used to convey the policy stance, particularly in the post-crisis period. Finally, we use the outstanding volume of total local currency (denar) loans, including loans with a foreign exchange clause, and the corresponding interest rate as market variables, in line with the fact that in a fixed exchange rate regime, monetary policy can only influence local currency loans. While most studies focus on loans to nonfinancial corporations, this is unfeasible in our case due to data limitations, as the series on corporate lending rates only starts in 2005. In addition, since the series on newly approved loans in Macedonia start at the end of 2005, we decided to use total outstanding loan volumes, which is in line with most other studies. 
Figure 2: Data Used in the Empirical Analysis
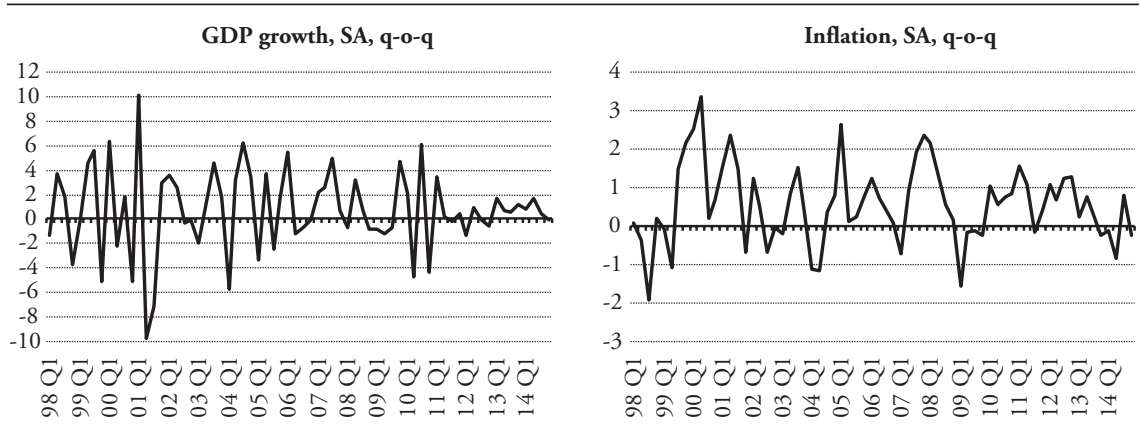

Policy rate (CB bills)

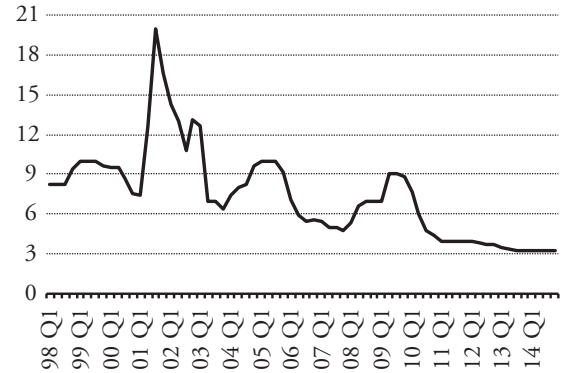

\section{Lending rates}

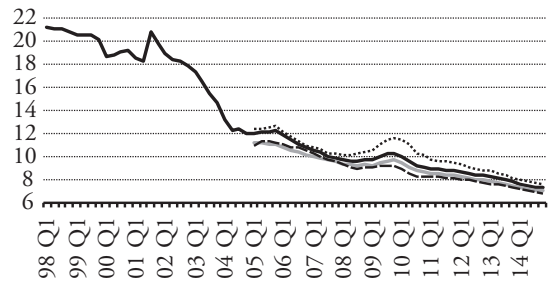

- Total denar loans

Total loans (denar and for. curr.)

...... Denar loans with FX clause

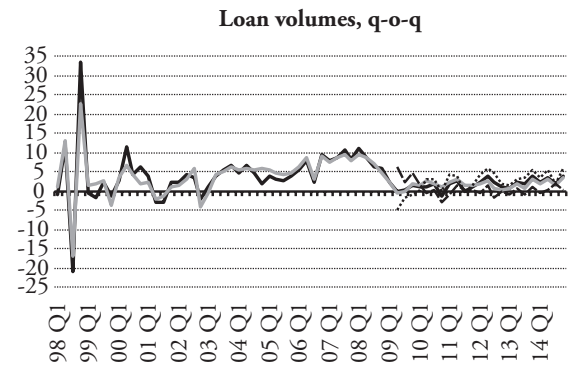


There is little agreement in the literature on loan supply shocks regarding the way the data should enter the VAR (except for interest rates, which generally enter untransformed, i.e., as percentage points). Empirical studies in this area employ various approaches, often with little or no explicit arguments for doing so. Busch, Scharnagl and Scheithauer (2010), Musso (2009) and Deryugina and Ponomarenko (2011) all use seasonally-adjusted log-levels. Hristov, Hülsewig and Wollmershäuser (2012) use linear detrending of all variables, including interest rates. Halvorsen and Jacobsen (2014) use a mix of detrended GDP, the inflation rate and the level of house prices. On the other hand, other studies use differenced data (Peersman, 2005; Mumtaz, Solovyeva and Vasilieva, 2012). We decided to follow the latter studies and use quarter-on-quarter percent changes of GDP and loans and the quarter-on-quarter inflation rate, while interest rates enter as percentages.

\subsection{Methodology}

Our empirical investigation is based on structural vector autoregression (SVAR) with sign restrictions. This method was first proposed in the context of monetary policy studies by Uhlig (2005), Canova and De Nicolo (2002) and Faust (1998) and is dominant in the recent empirical literature on loan supply shocks. We use Bayesian estimation with a normal inverse Wishart prior for the SVAR coefficients and the covariance matrix, with 10.000 Gibbs iterations and 1.000 retained draws ${ }^{2}$.

Since we have five endogenous variables in our model, we could identify at most five structural shocks. However, proceeding in this manner requires complicated identification restrictions and increases the computational burden (Busch, Scharnagl and Scheithauer, 2010). On the other hand, identifying only a few shocks can result in a large amount of unexplained movements. Studies on loan supply that use SVAR with sign restrictions identify two shocks at the 
least: the loan supply shock and the monetary policy shock. Busch, Scharnagl and Scheithauer (2010) explain this with the difficulties in disentangling the two shocks, which means that identifying only one of them would make the interpretation more complicated. Deryugina and Ponomarenko (2011) follow Busch, Scharnagl and Scheithauer (2010) by identifying the same two shocks in a five-variable VAR. In their study of Norway and the UK, Halvorsen and Jacobsen (2014) also identify only lending and monetary policy shocks within a six-variable VAR. On the other hand, besides the loan supply and monetary policy shocks, Musso (2009) also analyzes the effects of money demand and loan demand shocks on key macroeconomic variables in the euro area and the US. Tamási and Világi (2011) also identify four shocks in a seven-variable VAR in their analysis of the Hungarian economy. Finally, in their analysis of loan supply shocks in the euro area with a five-variable panel VAR with sign restrictions, Hristov, Hülsewig and Wollmershäuser (2012) identify four shocks: loan supply, monetary policy, aggregate demand and aggregate supply shocks.

We decided to closely follow Hristov, Hülsewig and Wollmershäuser (2012) and the literature surveyed therein in the identification of shocks for two main reasons. First, identifying several shocks enables a richer economic analysis (Paustian, 2007), i.e., it will enable us to disentangle their separate effects on key macroeconomic variables and to explain a bigger share of the latter. Second, Hristov, Hülsewig and Wollmershäuser (2012) impose sign restrictions based on a careful survey of other studies, particularly DSGE studies. Further, we only identify domestic shocks, thus following Hristov, Hülsewig and Wollmershäuser (2012), as well as the majority of other studies on other small open economies, e.g., Barnett and Thomas (2014) for the UK, Halvorsen and Jacobsen (2014) for Norway and the UK or Tamási and Világi (2011) for Hungary. On the other hand, Finlay and Jääskelä (2014) are one of the few to explicitly distinguish between domestic and foreign shocks when analyzing Australia, Canada and the UK. Besides being in line with most of the literature, this approach also reflects the main aim of our study, as we are interested in the overall effects of loan 
supply (and other macroeconomic) shocks, and not so much in their particular sources ${ }^{3}$. In addition, this means that the model is kept relatively simple and the interpretation is straightforward. On the other hand, with this approach we are unable to distinguish between sources of shocks, which might be important for a small open economy like Macedonia. In particular, we suspect such a distinction might be important for aggregate demand and supply shocks, albeit not so much for loan supply shocks, bearing in mind that lending in Macedonia is financed almost entirely by domestic deposits. In addition, the inclusion of foreign shocks could lower the unexplained part in the historical decomposition and the forecast error variance decomposition below.

We identify the following four shocks (Table 1): aggregate supply, monetary policy, aggregate demand and loan supply shocks, while there is also a fifth, unidentified shock. Shocks are defined as adverse shocks, but results are unchanged if all shocks are defined in an opposite manner. Most studies, including Hristov, Hülsewig and Wollmershäuser (2012), impose restrictions over several quarters, including more elaborate restrictions such as delayed reactions of some variables (Busch, Scharnagl and Scheithauer, 2010). In contrast, other studies impose contemporaneous restrictions only (Halvorsen and Jacobsen, 2014). Canova and Paustian (2011) recommend against imposing restrictions beyond the contemporaneous period, since they seldom have a clear theoretical underpinning. Bearing this in mind, we decided to only impose contemporaneous restrictions in our baseline specification, while below we also check the robustness of the baseline results to imposing restrictions in two quarters.

Restrictions for the identification ${ }^{4}$ of aggregate supply, aggregate demand and monetary policy shocks draw on the VAR studies by Peersman (2005) and Fratzscher, Saborowski and Straub (2009), as well as DSGE studies by Straub and Peersman (2006) and Canova and Paustian (2011). The aggregate supply shock is identified by imposing restrictions so that GDP growth and inflation move

3 See Jovanovikj and Georgievska (2015) and Unevska Andonova and Petkovska (2011) for the transmission and effects of foreign shocks on Macedonia.

4 This and the following paragraph draw heavily on Hristov, Hülsewig and Wollmershäuser (2012). 
in opposite directions, i.e., an adverse supply shock leads to a contemporaneous rise of prices and fall of GDP. As a reaction to these movements, the central bank reacts with higher interest rates. Aggregate supply shocks can be of various nature: shocks to the production function or production factors, shocks to labor or non-labor costs of production, shocks to the price-setting behavior, technology shocks or oil shocks (Musso, 2009). The policy shock is identified via tighter monetary policy (higher interest rates), which causes a contemporaneous fall of GDP and prices. Finally, in order to identify an aggregate demand shock, we restrict GDP growth and inflation to move in the same direction (i.e., they both fall). In such a case, the policy rate also falls as the central bank reacts with an expansionary policy. In addition, the negative aggregate demand shock is also accompanied by a contemporaneous fall of lending interest rates, for two main reasons. First, lower aggregate demand probably causes lower demand for loans, which is generally accompanied by lower lending rates. Second, the lower policy rate in the wake of the negative aggregate demand shock will also cause lower lending rates, even with incomplete transmission of monetary policy. Aggregate demand shocks may also be quite diverse, and may reflect changes in consumption or preference, investment demand shocks or fiscal policy shocks (Gambetti and Musso, 2012).

The identification of loan supply shocks also relies on the relevant literature. Loan supply shocks may reflect a combination of factors from the financial sector, such as changes in financing conditions, changes in competition, changes in the quality of borrowers (Hristov, Hülsewig and Wollmershäuser, 2012) or confidence effects. Further, when summarizing the relevant literature, Barnett and Thomas (2014) note that loan supply shocks could reflect factors such as worsening of bank assets, a decline in bank capital, an increase in the default risk or higher risk aversion by investors unrelated to credit default. In line with the general agreement in the theoretical and empirical literature, in the case of adverse loan supply shocks, the volume of outstanding loans falls, whereas the lending rate rises contemporaneously. Further, based on DSGE models with 
financial frictions and credit markets 5 , GDP growth also falls in the wake of loan supply shocks. On the other hand, there is some disagreement regarding the reaction of monetary policy and prices. Most studies find that the central bank relaxes its policy and prices fall in cases of loan supply shocks. Therefore, we also impose a restriction for the monetary policy to react to loan supply shocks by lowering the policy rate. However, prices are left unrestricted since other restrictions are sufficient for shock identification.

Table 1: Contemporaneous Sign Restrictions Imposed to Identify (Adverse) Structural Shocks (empty cells indicate no restrictions are imposed)

\begin{tabular}{|c|c|c|c|c|c|}
\hline & $\begin{array}{c}\text { GDP } \\
\text { growth }\end{array}$ & Inflation & Policy rate & $\begin{array}{l}\text { Lending } \\
\text { rate }\end{array}$ & $\begin{array}{c}\text { Loan } \\
\text { volume } \\
\text { change }\end{array}$ \\
\hline Aggregate supply shock & - & + & + & & \\
\hline Monetary policy shock & - & - & + & & \\
\hline Aggregate demand shock & - & - & - & - & \\
\hline Loan supply shock & - & & - & + & - \\
\hline
\end{tabular}

Source: Authors' calculations.

\section{Baseline Results}

Figure 3 shows impulse responses ${ }^{6}$ to an adverse aggregate supply shock. In line with the restrictions imposed, an adverse aggregate supply shock initially causes higher prices and lower GDP, with the central bank contemporaneously reacting by increasing the policy rate. The reaction of GDP and prices is short-lived, as their response quickly becomes insignificant and remains so throughout the horizon. The restrictive monetary policy is, however, more persistent and lasts for around a year. This indicates that the central bank responds rather strongly to adverse aggregate supply shocks, despite the usual recommendations that monetary policy should not do so unless the supply shock threatens to have second-round effects on inflation and inflationary expectations. The reaction of

5 See the survey in Hristov, Hülsewig and Wollmershäuser (2012).

6 In all cases we present median impulse responses, as well as confidence bands of 16 th and 84 th percentiles, in line with Sims and Zha (1999) and the relevant literature using sign restrictions. 
both lending rates and loan volumes to aggregate supply shocks is insignificant during the entire horizon.

Figure 3: Impulse Responses to an Aggregate Supply Shock
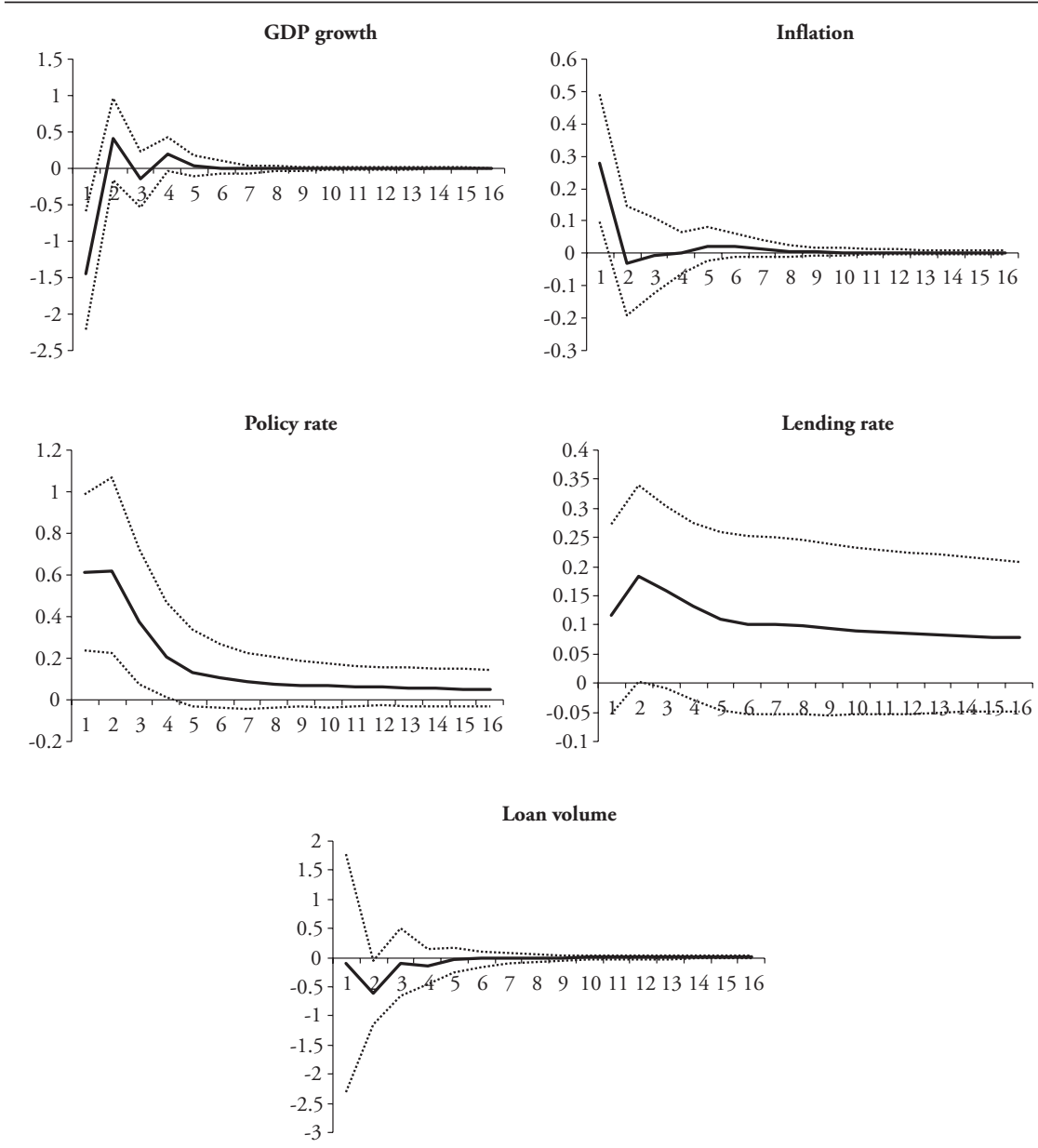

Source: Authors' calculations. 
Next, we analyze the response to a restrictive monetary policy shock (Figure 4). The policy rate rises on impact, in line with the sign restrictions, and this reaction is maintained for several quarters. This protracted reaction indicates some inertia in monetary policy decisions, which is to be expected. The restrictive monetary policy shock has a relatively strong effect on prices, which fall on impact, and remain significantly lower for about a year. On the other hand, the reaction of GDP is insignificant beyond the period of the restriction. This indicates that monetary policy does not affect inflation via economic activity, but its effect on prices is direct. One possible explanation for this would be that monetary policy affects inflationary expectations and then inflation due to the strong credibility of the central bank, which might be related to the relatively long and successful maintenance of the pegged exchange rate regime. Finally, the reaction of lending variables, which are left unrestricted, is insignificant throughout the period.

The insignificant reaction of lending rates (and volumes) indicates a weak monetary policy transmission mechanism, which is broadly in line with findings from other studies regarding the transmission of policy rates to other interest rates in Macedonia (Veličkovski, 2006; Bogoev and Petrevski, 2012). Further, our finding of an insignificant effect of monetary policy shocks on GDP is similar to Jovanovic, Krstevska and Popovska-Kamnar (2015), who use a smaller VAR with recursive identification over a similar period in Macedonia, although they do find some evidence of weak effects of monetary policy when using regimeswitching VARs and other monetary policy instruments. On the other hand, unlike their finding of insignificant response of inflation, we find that monetary policy shocks do have a direct effect on price movements. 
Figure 4: Impulse Responses to a Monetary Policy Shock
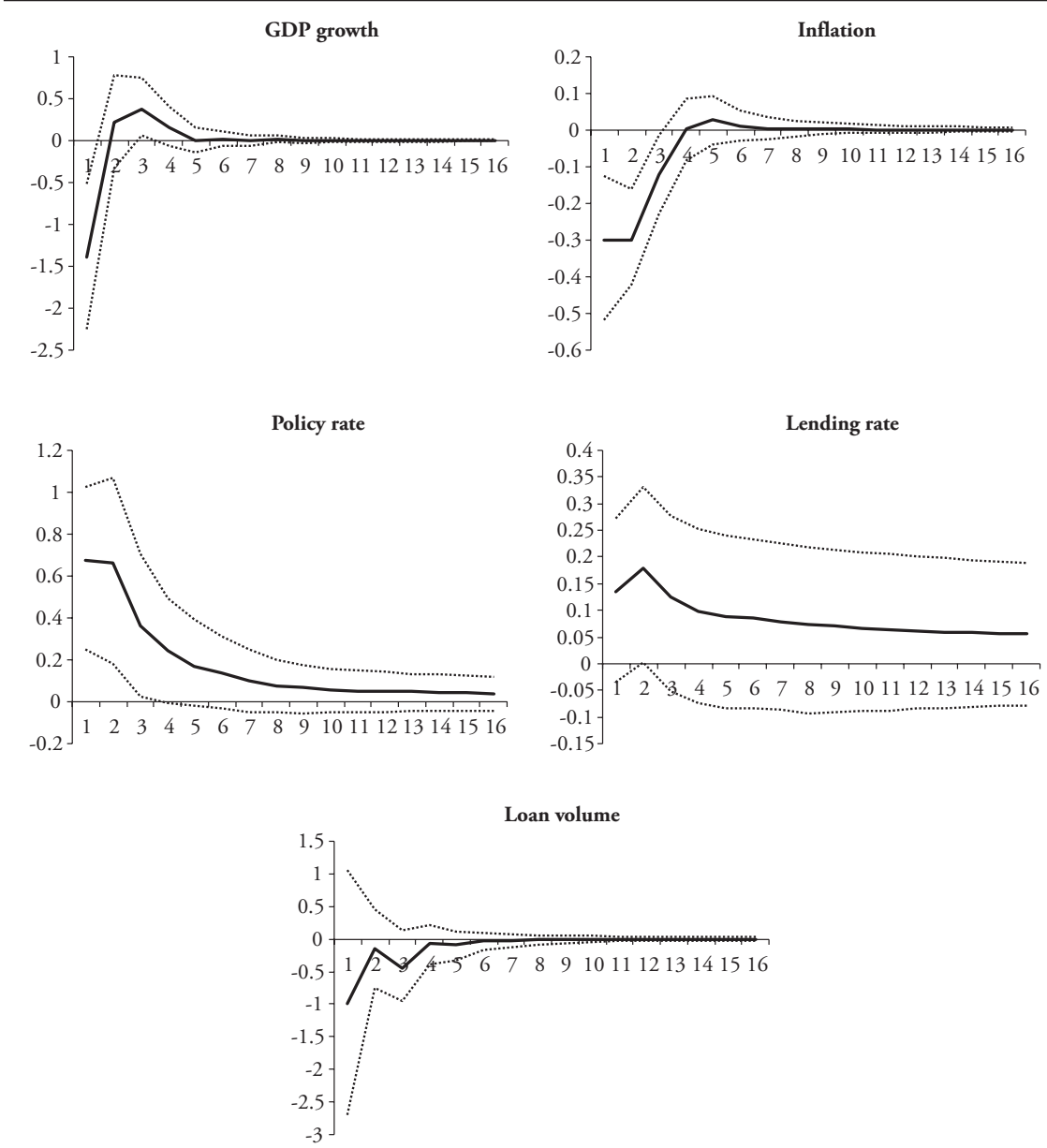

Source: Authors' calculations.

Figure 5 shows impulse responses to an adverse aggregate demand shock. GDP falls on impact, in line with the restrictions imposed, but immediately jumps back the following quarter before becoming insignificant. Also in line with the restrictions imposed, both prices and the policy rate fall on impact. The reaction of prices becomes insignificant soon thereinafter, while the policy rate remains 
significantly lower for a relatively long period, which indicates that adverse demand shocks are met with a relatively long-lived reaction by the central bank with a more relaxed policy. The lending rate falls on impact, and this reaction is quite persistent, as it remains significant for over four years, thus mirroring the lower policy rates. On the other hand, the response of the loan volume is insignificant, which is somewhat surprising given the lower lending rates.

Figure 5: Impulse Responses to an Aggregate Demand Shock
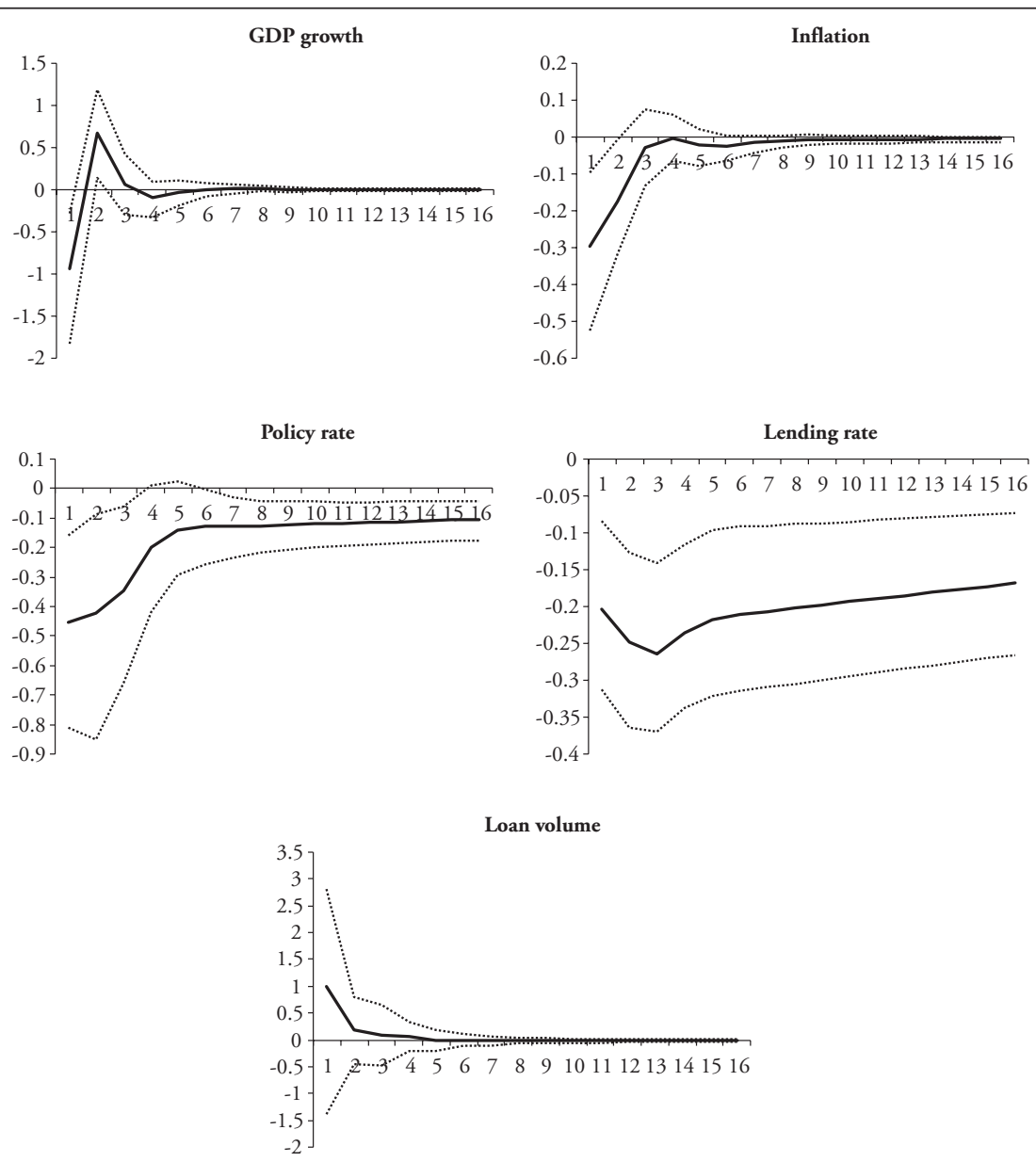

Source: Authors' calculations. 
Finally, Figure 6 shows the reaction to an adverse loan supply shock. In line with the sign restrictions, the loan supply shock initially causes opposite movements of loan volumes and rates. This effect on lending rates is quite prolonged, as they are higher for quite a long period, although both lending rates and volumes become insignificant fairly quickly. The impact on other variables is quite limited. GDP falls on impact due to the restriction, but is insignificant thereinafter.

Figure 6: Impulse Responses to a Loan Supply Shock
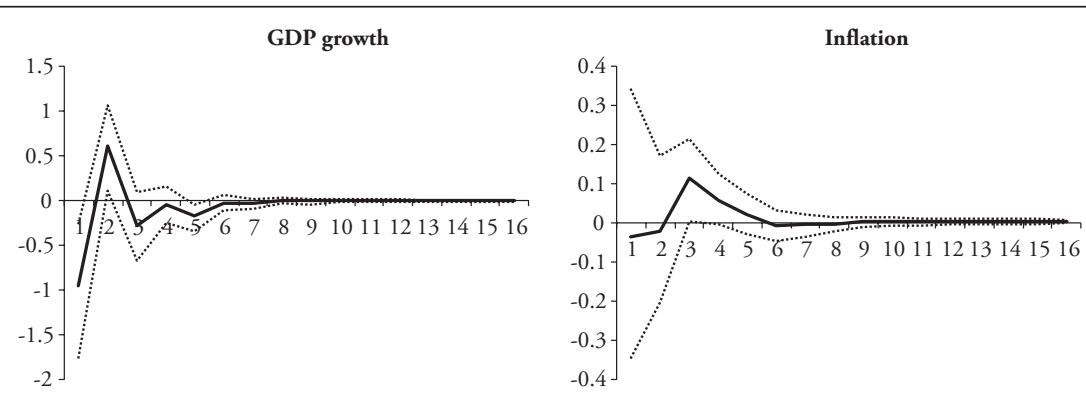

Policy rate
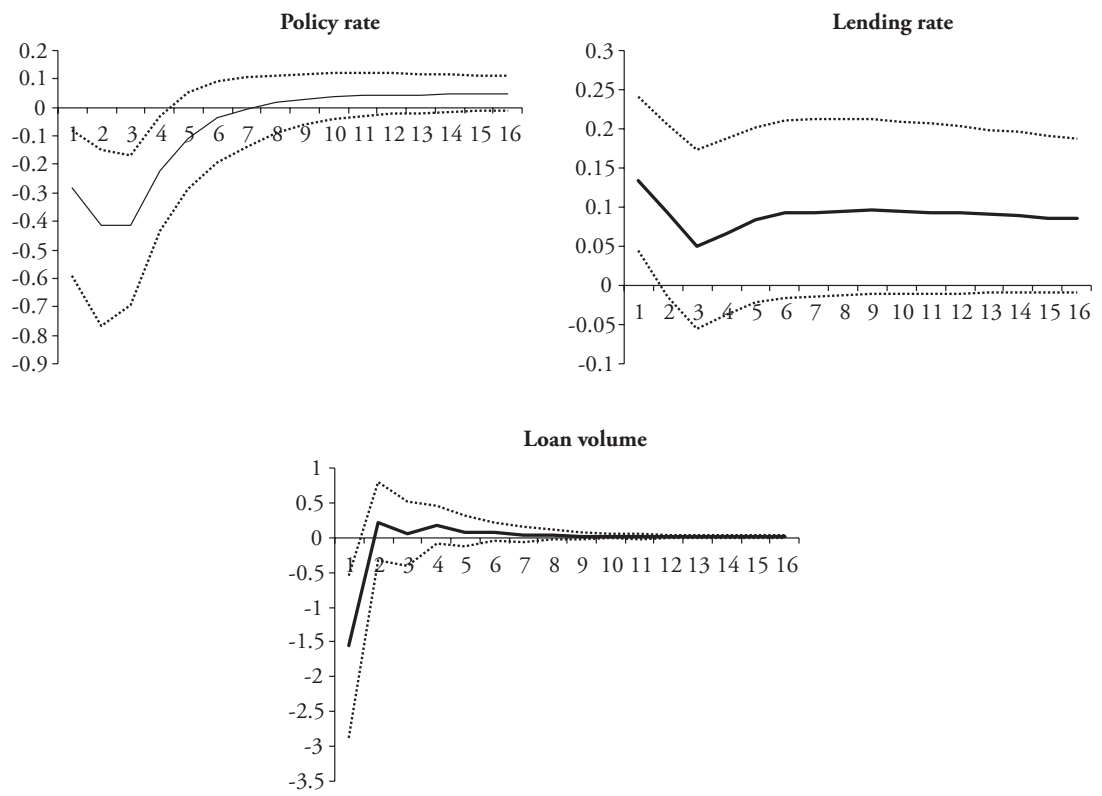

Source: Authors' calculations. 
The response of inflation, which is left unrestricted, is insignificant throughout the period. The only reaction that is significant for a longer period is the one of monetary policy, which reacts with lower rates on impact due to the sign restrictions, and is more relaxed for about a year after the adverse loan supply shock. Overall, this implies that, if the supply of loans falls, the central bank tries to counteract by relaxing its policy, which is usually successful, since loan supply shocks do not result in a significant decline in loan volumes, and they also do not cause a contraction in GDP and a fall in prices.

Table 2 presents results of the forecast error variance decomposition (FEVD). The left panel indicates that aggregate supply and monetary policy are the main drivers of economic activity, as their shocks each explain around a fifth of the forecast error variance of GDP growth. Loan supply shocks explain around 10 percent of the variance of GDP on impact, and this share rises to around 13 percent for the variance after a year. The right panel shows the contribution of loan supply to the FEVD of all variables. Besides the noted effect on GDP, loan supply shocks also explain between 10 and 13 percent of the variance of prices and loan volumes, while their effect on lending rates is somewhat lower.

Table 2: Forecast Error Variance Decomposition (FEVD) - Baseline Specification

\begin{tabular}{|c|c|c|c|c|}
\hline \multicolumn{5}{|c|}{ FEVD of q-o-q detrended GDP } \\
\hline & $\begin{array}{c}A t \\
\text { impact }\end{array}$ & $\begin{array}{c}\text { After } 1 \\
\text { year }\end{array}$ & $\begin{array}{c}\text { After } 3 \\
\text { years }\end{array}$ & $\begin{array}{c}\text { After } 5 \\
\text { years }\end{array}$ \\
\hline \multicolumn{5}{|c|}{ Contributions of: } \\
\hline $\begin{array}{l}\text { Unidentified } \\
\text { shocks }\end{array}$ & 39.1 & 35.2 & 34.7 & 34.7 \\
\hline $\begin{array}{l}\text { Aggregate } \\
\text { supply shocks }\end{array}$ & 22.3 & 20.2 & 20.4 & 20.4 \\
\hline $\begin{array}{l}\text { Monetary } \\
\text { policy shocks }\end{array}$ & 20.1 & 19.1 & 19.2 & 19.2 \\
\hline $\begin{array}{l}\text { Aggregate } \\
\text { demand } \\
\text { shocks }\end{array}$ & 9.2 & 12.9 & 12.9 & 12.9 \\
\hline $\begin{array}{l}\text { Loan supply } \\
\text { shocks }\end{array}$ & 9.4 & 12.6 & 12.8 & 12.8 \\
\hline
\end{tabular}

\begin{tabular}{l|c:c:c:c}
\hline \multicolumn{3}{c}{ Contributions of the loan supply shock } \\
& $\begin{array}{c}\text { At } \\
\text { impact }\end{array}$ & $\begin{array}{c}\text { After 1 } \\
\text { year }\end{array}$ & $\begin{array}{c}\text { After 3 } \\
\text { years }\end{array}$ & $\begin{array}{c}\text { After 5 } \\
\text { years }\end{array}$ \\
\hline $\begin{array}{l}\text { To the FEVD of: } \\
\text { GDP } \\
\text { growth }\end{array}$ & 9.4 & 12.6 & 12.8 & 12.8 \\
\hdashline $\begin{array}{l}\text { Inflation } \\
\text { Policy }\end{array}$ & 9.6 & 11.6 & 11.8 & 11.8 \\
rate & 4.4 & 9.5 & 10.0 & 10.4 \\
$\begin{array}{l}\text { Lending } \\
\text { rate }\end{array}$ & 9.7 & 5.2 & 6.5 & 6.9 \\
$\begin{array}{l}\text { Loan } \\
\text { volume }\end{array}$ & 11.8 & 12.1 & 12.5 & 12.5 \\
\hline
\end{tabular}

Note: The left panel shows the contribution in percent of each shock to the forecast error variance of q-o-q detrended GDP at various horizons. The right panel shows the contribution in percent of the loan supply shock to the FEVD of each variable at various horizons.

Source: Authors' calculations. 
In order to analyze the recent crisis, we also present the historical decomposition between 2007Q1 and 2014Q4. In line with other studies (Barnett and Thomas, 2014; Finlay and Jäskelä, 2014), Figure 7 shows the decomposition of deviations of variables from their trend values instead of actual variables. For ease of exposition, decompositions of GDP, inflation and loan volumes are presented in year-on-year terms.

Results in Figure 7 lend additional support to our decision to identify several structural shocks, since they display a rich and plausible economic interpretation. The decomposition of year-on-year GDP growth indicates that, in the period immediately preceding the crisis, above-trend GDP growth was mostly driven by accommodative monetary policy, with additional contributions by loan supply and buoyant aggregate demand. As the crisis hit, growth slowed down markedly during the second half of 2008 and particularly during 2009, mostly as a result of the more restrictive monetary policy, which during this period was focused on stopping the loss of foreign exchange reserves and stabilizing expectations. Negative aggregate supply shocks in the wake of rising uncertainty and volatility in global financial markets had an additional effect on the fall of GDP. The post-crisis recovery shows changing contribution of factors. In the immediate aftermath of the crisis and in circumstances of stabilized movements of foreign exchange reserves, recovery was supported by monetary policy, whose contribution to growth was positive until the middle of 2011. Thereinafter, with a few exceptions, the contribution of monetary policy to GDP growth until the end of 2014 is mostly negative, but relatively low? The supply of loans has a relatively strong supportive role in GDP growth before and during the crisis, but its effect becomes negative in the second half of 2010 and remains so throughout the period, thus reflecting the effects of continued uncertainty and heightened risk aversion by banks. Although comparatively smaller, the contribution of aggregate demand follows a similar pattern. On the other hand, while aggregate

7 This result should be qualified since the post-crisis monetary policy also relies on additional instruments which are not captured by the policy rate that is used in our analysis to represent monetary policy, as noted above. For empirical evidence on the effects of additional instruments used by the NBRM, see Jovanovic, Krstevska and Popovska-Kamnar (2015). 
supply shocks were dragging down GDP growth in the period immediately preceding and during the crisis, their effect in the last two years is positive, which probably reflects the lack of global and domestic inflationary pressures.

The second panel of Figure 7 indicates a relatively strong contribution of monetary policy shocks to inflation, which is in line with impulse responses analyzed previously. Monetary policy contributed considerably to the high inflation before the crisis and the falling inflation during the crisis, while its effect is weaker during the recovery. The contribution of other factors is relatively small, as aggregate supply, aggregate demand and loan supply shocks all contributed to higher inflation before the crisis and lower inflation during the crisis, and they also help explain price movements during the recovery.

Determinants of the policy rate vary across the period. Accommodative policy rates during the pre-crisis boom are mostly due to policy shocks (and unidentified factors). In the wake of the crisis, policy rates were tightened mostly as a result of monetary policy shocks, reflecting the determination of the central bank to stop the loss of foreign exchange reserves, while there was an additional contribution by aggregate supply shocks and unidentified factors. On the other hand, during the recovery, the below-trend movement of policy rates is mostly explained by loan supply shocks, thus confirming the previous finding that monetary policy tries to counteract negative loan supply movements.

The last two panels show that loan supply shocks have a stronger impact on lending rates than on loan volumes. In particular, they contribute to downward movements of lending rates almost throughout the period analyzed. During the crisis, above-trend lending rates are partially explained by more restrictive policy rates, whereas before and after the crisis monetary policy contributes to lower lending rates. On the other hand, all the shocks contribute positively to the above-trend loan volume changes before the crisis, with monetary policy shocks exerting the strongest influence. As the crisis hit, the combined effect of factors became negative, thus driving and keeping loan volumes below trend until the end of the sample. 


\section{Figure 7: Historical Decomposition}

Historical decomposition of detrended Y-o-Y GDP growth

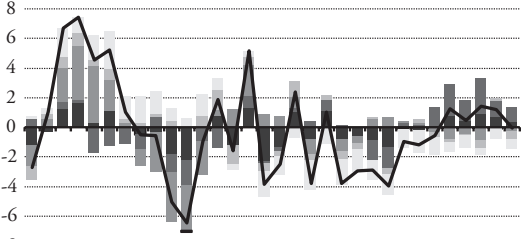

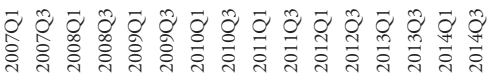

\begin{tabular}{|c|c|}
\hline $\begin{array}{l}\text { Unidentified } \\
\text { Mon. policy shock } \\
\text { Loan supply shock }\end{array}$ & $\begin{array}{l}\text { Agg. supply shock } \\
\text { Agg. demand shock } \\
\text { _ GDP-detrended (y-o-y) }\end{array}$ \\
\hline
\end{tabular}

Historical decomposition of detrended policy rate

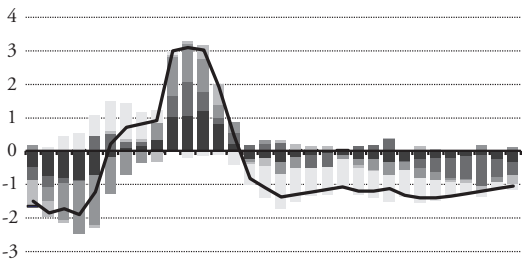

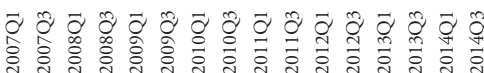

$\begin{array}{cc}\text { Unidentified } & \text { Agg. supply shock } \\ \text { Mon. policy shock } & \text { Agg. demand shock } \\ \text { Loan supply shock } & \text { - Policy rate-detrended }\end{array}$

Historical decomposition of detrended Y-o-Y inflation

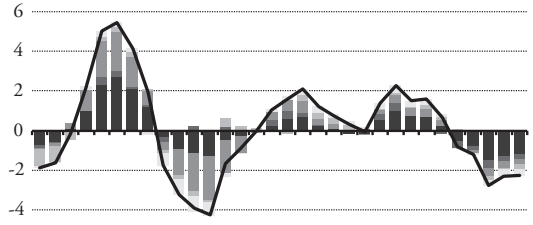

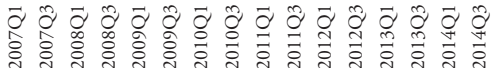

$\begin{array}{ll}\text { Unidentified } & \text { Agg. supply shock } \\ \text { Mon. policy shock } & \text { Agg. demand shock } \\ \text { Loan supply shock } & \text { - Policy rate-detrended }\end{array}$

Historical decomposition of detrended lending rate

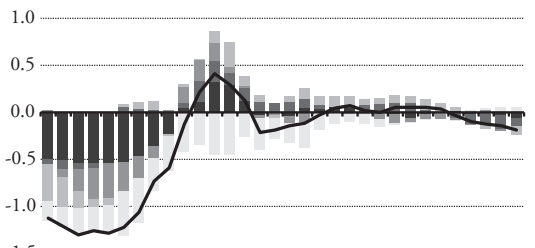

$-1.5$

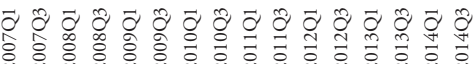

- Unidentified Agg. supply shock

Mon. policy shock Agg. demand shock

Loan supply shock _ Lending rate-detrended

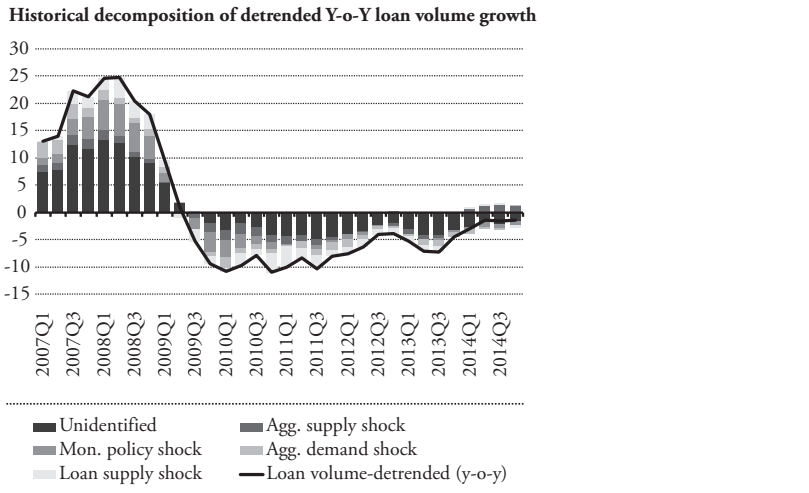

Source: Authors' calculations. 


\section{Robustness Checks}

An important issue of interest is whether baseline results are an artefact of the particular duration of the sign restrictions imposed to identify the shocks. In the baseline specification, restrictions are imposed only contemporaneously, whereas the responses are left unrestricted thereinafter. In the alternative specification, we try to capture the delay that might be characteristic for some of the relations analyzed, since some of these variables may be more inertial and not react immediately to shocks. Therefore, we impose the same restrictions not only contemporaneously, but also for an additional period, i.e., restrictions are imposed in two quarters. Figure 8 shows that responses with this alternative specification are fairly similar to the baseline results, and this applies to the magnitude, the sign and the significance of responses. The only difference appears in the significance of responses of lending rates to monetary policy and loan supply shocks. In particular, unlike the insignificant responses in the baseline specification, the lending rate responds significantly to these shocks when the alternative restrictions are used, thus yielding results that are more plausible. The rise of lending rates in the wake of an adverse monetary policy shock is now significant for more than a year, thus strengthening the previous finding from the baseline analysis that monetary policy is transmitted via lending rates (and not lending volumes). The alternative restrictions also strengthen the finding that loan supply shocks are mostly manifested through higher lending interest rates, despite a more accommodative monetary policy in this case. However, this reaction of lending rates to loan supply shocks is now significant, whereas we confirm the insignificant response of loan volumes. 


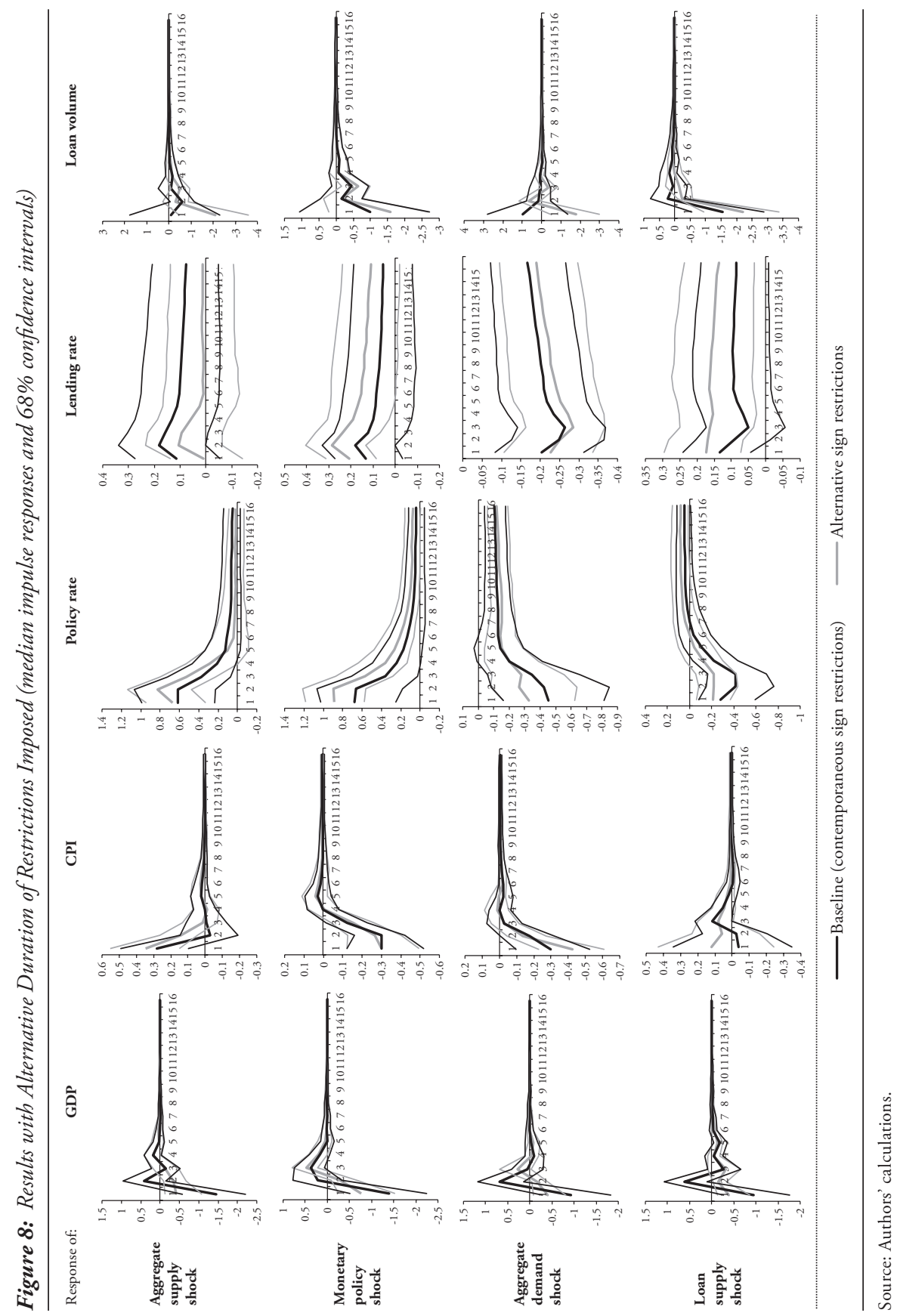


We also wanted to check whether our results hold across the entire period, or are there any structural breaks or differences in the response of the variables to shocks. Such an analysis could be performed by using time-varying parameter VAR, which is, however, unfeasible in our case due to the length of available data series. Therefore, we carry out the stability analysis by using rolling 10 -year VARs with one-year steps, i.e., we have eight subsamples: the first one for the 1998-2007 period and the last one for the 2005-2014 period. In Figure 9 we compare the impulse responses from the rolling regressions with the baseline results. Although the split considerably shortens the sample and thus yields less precise results, it is reassuring that the baseline results are very robust. Indeed, in the vast majority of cases, impulse responses from the rolling regressions are within the 68 percent confidence interval of the baseline responses.

We also carried out two additional checks of baseline results ${ }^{8}$. Results are fairly similar if the variables enter the VAR with four lags, with only minimal differences in the magnitude of some responses. This lends further support to our decision to use two lags, since a fourth-order VAR would have fewer degrees of freedom. On the other hand, several responses have a different magnitude and sometimes even a different sign if only one lag is included in the VAR. This probably reflects the severe residual autocorrelation in the first-order VAR, which points towards biased results in this case.

In another check, we replaced local currency with total loan volumes and corresponding total lending rates. Although untypical, such a definition might be appropriate in the case of Macedonia due to the sizeable euroization and the possible effects of monetary policy decisions on the portfolio mix between local and foreign currency holdings and loans. However, differences between the two specifications were fairly small, probably reflecting the similar movements of the denar and total loans and the corresponding lending rates (Figure 2).

8 These results are not shown, but are available from the authors on request. 


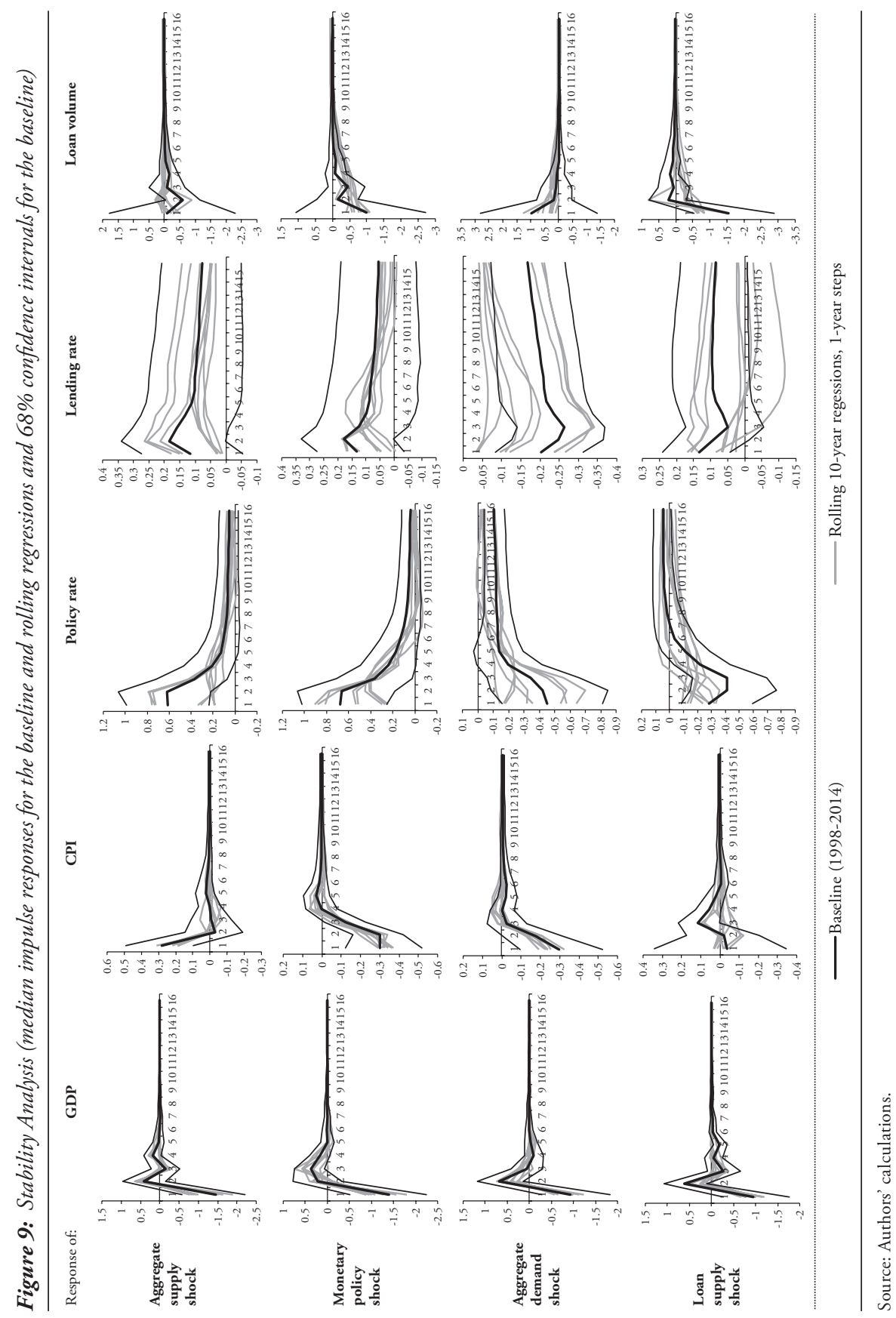




\section{Conclusion}

This study examines the dynamics of loan supply and relations to macroeconomic and policy factors in Macedonia between 1998 and 2014 by using the Bayesian SVAR model with sign restrictions. The paper relies on the available theoretical and empirical literature to identify four structural shocks and their effects on key macroeconomic, policy and lending variables. To the best of our knowledge, it is the first paper to investigate lending and monetary policy in Macedonia using Bayesian methods.

We find that, somewhat surprisingly, loan supply shocks have no significant effect on either loan volumes or lending rates, and their effects on economic activity and prices are also limited. Baseline results show that monetary policy shocks have limited effects on lending variables, but relatively strong effects on inflation, which indicates that monetary policy is effective in achieving its main aim. On the other hand, the response of monetary policy to aggregate demand and loan supply shocks is quite strong and in line with expectations. Monetary policy also reacts strongly to aggregate supply shocks, in line with the importance attached by the central bank to maintaining low and stable inflation.

The analysis also indicates that loan supply was supporting economic growth before and during the crisis, but its contribution became negative during the recovery and it continued to act as a drag on growth until the end of 2014. In the period preceding the global crisis, monetary policy was one of the key factors driving above-trend GDP growth. When the crisis hit in late 2008 and in 2009, the effect of monetary policy turned to negative, as it was trying to stop the loss of foreign exchange reserves and stabilize expectations. Once this was achieved and monetary policy was relaxed, its contribution to the recovery became positive, although the effect in recent years is again mildly negative. Further, policy rates in recent years are mostly explained by subdued lending activity and aggregate supply factors, which the central bank tries to counteract with a more accommodative policy. 
Robustness checks confirm our main findings and provide some additional insights. In particular, the baseline results are robust to imposing restrictions for a longer period, although in this case we find a more plausible result of stronger and significant reaction of lending rates to monetary policy and loan supply shocks.

\section{Literature}

Barnett, Alina and Ryland Thomas, 2014, "Has Weak Lending and Activity in the UK Been Driven by Credit Supply Shocks?", Manchester School, 82(S1), pp. 60-89. http://dx.doi.org/10.1111/manc.12071

Blake, Andrew and Haroon Mumtaz, 2012, Technical Handbook No. 4-Applied Bayesian Econometrics for Central Bankers, London: Centre for Central Banking Studies, Bank of England.

Bogoev, Jane and Goran Petrevski, 2012, "Interest Rate Pass-Through in a Small Open Economy with a Fixed Exchange Rate - The Case of Macedonia”, Procedia - Social and Behavioral Sciences, 44, pp. 125-133. http://dx.doi.org/10.1016/j. sbspro.2012.05.012

Busch, Ulrike, Michael Scharnagl and Jan Scheithauer, 2010, "Loan Supply in Germany during the Financial Crisis", Deutsche Bundesbank Economic Studies Discussion Paper, No. 05/2010, Frankfurt: Deutsche Bundesbank.

Canova, Fabio and Gianni De Nicolo, 2002, "Monetary Disturbances Matter for Business Fluctuations in the G-7", Journal of Monetary Economics, 49(6), pp. 1131-1159. http://dx.doi.org/10.1016/S0304-3932(02)00145-9

Canova, Fabio and Matthias Paustian, 2011, "Business Cycle Measurement with Some Theory", Journal of Monetary Economics, 58(4), pp. 345-361. http://dx.doi. org/10.1016/j.jmoneco.2011.07.005 
Deryugina, Elena B. and Alexey A. Ponomarenko, 2011, "Identifying Structural Shocks Behind Loan Supply Fluctuations in Russia", BOFIT Discussion Papers, No. 20/2011, Helsinki: BOFIT - Institute for Economies in Transition, Bank of Finland.

Faust, Jon, 1998, "The Robustness of the Identified VAR Conclusions about Money", Carnegie-Rochester Conference Series on Public Policy, 49, pp. 207-244. http://dx.doi.org/10.1016/S0167-2231(99)00009-3

Finlay, Richard and Jarkko P. Jääskelä, 2014, "Credit Supply Shocks and the Global Financial Crisis in Three Small Open Economies", Journal of Macroeconomics, 40, pp. 270-276. http://dx.doi.org/10.1016/j.jmacro.2014.01.006

Fratzscher, Marcel, Christian Saborowski and Roland Straub, 2009, "Monetary Policy Shocks and Portfolio Choice”, ECB Working Paper Series, No. 1122, December, Frankfurt: ECB.

Gambetti, Luca and Alberto Musso, 2012, "Loan Supply Shocks and the Business Cycle”, ECB Working Paper Series, No. 1469, September, Frankfurt: ECB.

Halvorsen, Jørn I. and Dag Henning Jacobsen, 2014, "How Important Can Bank Lending Shocks Be for Economic Fluctuations?", The North American Journal of Economics and Finance, 29, pp. 104-123. http://dx.doi.org/10.1016/j. najef.2014.05.006

Hristov, Nikolay, Oliver Hülsewig and Timo Wollmershäuser, 2012, "Loan Supply Shocks during the Financial Crisis: Evidence for the Euro Area", Journal of International Money and Finance, 31(3), pp. 569-592. http://dx.doi.org/10.1016/j. jimonfin.2011.10.007

Jovanovic, Branimir, Aneta Krstevska and Neda Popovska-Kamnar, 2015, "Can Monetary Policy Affect Economic Activity under Surplus Liquidity? Some Evidence from Macedonia", National Bank of the Republic of Macedonia 
Working Paper, No. 2015-03, Skopje: National Bank of the Republic of Macedonia.

Jovanovikj, Biljana and Ljupka Georgievska, 2015, “Transmission Channels of the Global Economic Crisis: Micro Evidence for Macedonia”, Journal of Contemporary Economic and Business Issues, 2(1), pp. 5-20.

Mumtaz, Haroon, Alexandra Solovyeva and Elena Vasilieva, 2012, "Asset Prices, Credit and the Russian Economy”, CCBS Joint Research Paper, No. 1, London: Centre for Central Banking Studies, Bank of England.

Musso, Alberto, 2009, "Money and Credit over the Business Cycle", ECB, unpublished paper, January.

Paustian, Matthias, 2007, "Assessing Sign Restrictions", The B.E. Journal of Macroeconomics, 7(1), pp. 1-33. http://dx.doi.org/10.2202/1935-1690.1543

Peersman, Gert, 2005, "What Caused the Early Millennium Slowdown? Evidence Based on Vector Autoregressions", Journal of Applied Econometrics, 20(2), pp. 185-207. http://dx.doi.org/10.1002/jae.832

Sims, Christopher A. and Tao Zha, 1999, "Error Bands for Impulse Responses", Econometrica, 67(5), pp. 1113-1155. http://dx.doi.org/10.1111/1468-0262.00071

Straub, Roland and Gert Peersman, 2006, "Putting the New Keynesian Model to a Test”, IMF Working Paper, No. 06/135, May, Washington, DC: IMF.

Tamási, Bálint and Balázs Világi, 2011, "Identification of Credit Supply Shocks in a Bayesian SVAR Model of the Hungarian Economy”, Magyar Nemzeti Bank Working Papers, No. 2011/7, Budapest: Magyar Nemzeti Bank.

Uhlig, Harald, 2005, "What Are the Effects of Monetary Policy on Output? Results from an Agnostic Identification Procedure", Journal of Monetary Economics, 52(2), pp. 381-419. http://dx.doi.org/10.1016/j.jmoneco.2004.05.007 
Unevska Andonova, Danica and Marija Petkovska, 2011, "The Transmission of External Shocks to the Macedonian Economic Activity", National Bank of the Republic of Macedonia Working Paper, No. 2011-03, Skopje: National Bank of the Republic of Macedonia.

Veličkovski, Igor, 2006, "Monetary Transmission Through the Interest Rate Channel and The Financial Markets in Macedonia: What Have We Done, What Have We Achieved and What Have We Learned?", National Bank of the Republic of Macedonia Working Paper, No. 2006-03 (in Macedonian), Skopje: National Bank of the Republic of Macedonia. 